\title{
Effect of Temperature, Storage Containers and Improved Hygiene on Microbial Safety and Chemical Quality of Traditional Meat Products
}

\author{
Buke G. Dabasso, Anselimo O. Makokha, Arnold N. Onyango, \\ Julius M. Mathara and Qabale D. Badake
}

\section{ABSTRACT}

Preservation of meat and meat products is important due to its short shelf life and perishability. The pastoralists of Northern Kenya processed and preserved traditional meat products for consumption. The traditional meat products are relished food both for nutritional and cultural heritage among the Borana pastoralists. The study was carried out to assess the microbial safety and chemical quality of traditional meat products. The samples were collected immediately after processing and transported in a cool box to the food laboratory for microbial analysis and determination of changes related to lipid oxidation during storage for seven weeks at ambient temperature and at refrigerated temperature $\left(5^{\circ} \mathrm{C}\right)$. Microbiological quality of the samples was assessed by Total Viable Count (TVC), Escherichia coli count, Staphylococcus aureus count and yeast and mold count. Result showed that Staphylococcus aureus, yeasts and molds were detected in the products and there was increase of Staphylococcus aureus count from $\left(1.44 \log _{10} \mathrm{CFU} / \mathrm{g}\right)$ to $\left.\left(2.28 \log _{10} \mathrm{CFU} / \mathrm{g}\right)\right)$ during storage at ambient temperature for seven weeks. Samples stored at refrigerated $5^{\circ} \mathrm{C}$ showed less counts of microbial load. The peroxide value, acid value and thiobarbituric acid levels were below the value associated with meat spoilage during the expected shelf life. Reduction of moisture during drying of traditional meat products and cooking of meat at high temperature contributed towards reduction of microbial load. However, poor handling and post contamination may lead to poor microbial quality of traditional meat products.

Keywords: meat products, microbial, quality, safety, traditional.
Submitted : June 03, 2021

Published : August 24, 2021

ISSN: $2684-1827$

DOI: 10.24018 /ejfood.2021.3.4.317

Buke G. Dabasso*

Kenya Agricultural and Livestock

Research Organization, Kenya.

(e-mail: buke.galma@ ${ }^{@ m a i l . c o m) ~}$

Anselimo O. Makokha

Jomo Kenyatta University of

Agriculture and Technology, School of Food and Nutrition Sciences, Kenya.

Arnold N. Onyango

Jomo Kenyatta University of Agriculture and Technology, School of Food and Nutrition Sciences, Kenya. Julius M. Mathara

Jomo Kenyatta University of Agriculture and Technology, School of Food and Nutrition Sciences, Kenya. Qabale D. Badake

Kenya Agricultural and Livestock Research Organization, Kenya.

*Corresponding Author

\section{INTRODUCTION}

The Borana women prepared traditional meat products from beef or goat meat, which was striped, dried, and deep fried. It has a high cultural and economic importance to Borana people which explains the efforts to ensure quality and microbial safety. The processing and preparation of these traditional meat products was an elaborate process where the meat parts used were selected carefully by removing fatty tissues, ligaments and only lean meats parts were used. The meat was then striped and suspended to dry for one to three days to lower the moisture content. According to [1] meat products, when not consumed immediately, are often processed using a range of traditional techniques involving salting, drying, cooking, smoking, and marinating, or a combination of these operations to lengthen their shelf life.

Due to handling and preparation environment of traditional meat products, microbial contamination can arise from post handling even after high temperature has been used to kill the microorganisms during processing. Food handlers can act as vectors for food contamination leading to the transmission of enteric and respiratory pathogens to food, the composition of the residual predominant microbiota in food products is also known to be determined by the handling, processing, and storage conditions. Interaction of all these predisposing factors could explain the principal bacterial populations associated with biltong [2].

Raw meat is a perishable product which is prone to spoilage and deterioration. It is important to observe hygiene from the point of slaughter through all stages of processing to storage to maintain high quality and safety. There are three main mechanisms for meat and meat products spoilage these are microbial spoilage, lipid oxidation and autolytic enzymatic spoilage [3]. Meat used for drying amongst pastoralists is usually derived from fresh carcasses Traditional dried meat are usually cut into slice and sun dried Reducing the moisture content of the meat is achieved by evaporation of water from the peripheral zone of the meat to the surrounding air and the continuous migration of water from the deeper meat layers to the peripheral zone [4]. Similar traditional meat product such as pemmican was dried in the sun and pounded or shredded prior to being mixed with the melted fat. This preserving method is based on the air exclusion provided by the fat, which reduces oxidative changes and diminishes microbial growth [5] Because 
microbial quality of meat products is of public health concern all over the world it is important to determine the microbial safety of these products. Processed meat foods are more prone to contamination with pathogenic microorganisms during the various stages of processing [6] Moreover, since these products are preserved in oil, the possibility that lipid oxidation and the associated rancidity and production of harmful lipid oxidation products should be considered. Microbiological assessment on safety, storage stability, and sanitary quality of traditional meat products were carried out to analyses for the presence of some pathogens like Staphylococcus aureus, different microbial groups (e.g., Total Viable Counts and yeast and molds), and indicator bacteria (e.g., E. coli as an indicator of sanitation). The variation in bacterial count between different types of meat products could be attributed to difference of ingredients and steps involved in their formulation and preparation [7].

\section{Materials AND METHODS}

\section{A. Preparation of Traditional Meat Products and Collection of Samples}

Meat products were striped and dried for one to three days at prevailing temperature conditions and later deep fried as shown in (Fig. 1) below. The women also prepared products under improved condition where basic hygiene of washing hands at critical stages were observed. The basic hygiene practices applied to improved products included observation of personal hygiene, washing of hands, cleaning and sanitizing of knives, pots and other utensils used.

The samples were then transported in a cool box immediately after collection to the Department of Food Science and Technology at Jomo Kenyatta University of Agriculture and Technology (JKUAT). At the laboratory samples were stored at different treatment condition, ambient temperature, and refrigerated temperature at $5^{\circ} \mathrm{C}$ and analysed for microbial load and rancidity indices using method [8]

Microbiological assessment was done to establish the microbial safety and chemical quality of traditional meat products as microorganisms are the main cause of spoilage in meat. Aerobic colony count was done as count of total viable bacteria employed to indicate the sanitary quality of food. Indicator organism, Escherichia coli was tested for any direct or indirect faecal contamination. Specific pathogen counts of Staphylococcus aureus was done to check presence of microorganisms that may cause food borne illness while yeast and molds counts was done as an indicator of food spoilage. Quality indices such as peroxide value, acid value, free fatty acid, Thiobarbituric acid (TBA) and pH were also assessed to evaluate development of rancidity in traditional meat products.

The conditions which were tested were time (seven weeks) bi-weekly, temperature (ambient and refrigerated $5^{\circ} \mathrm{C}$ ), different storage containers (universal glass bottles, traditional containers, and stainless steel containers) and products prepared under improved conditions
Lean Beef or Goat meat

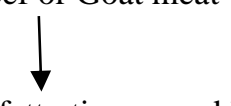

Sorting to remove fatty tissues and ligaments

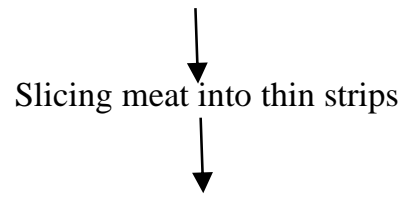

Drying the sliced meat at ambient $\mathrm{T}^{\circ} \mathrm{C}$ for 1-3 days<smiles>C[Te]</smiles>

Cutting the dried meat into small pieces<smiles>[Te]C[Te]</smiles>

Deep frying cut meat at $120-200{ }^{\circ} \mathrm{C}$ for $15-20$ minutes

Addition of salt and spices

Cooling cooked meat products for at least 10 hours

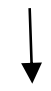

Samples collected in universal bottles, traditional containers and stainless steel jugs

Transportation of samples to food laboratory

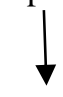

Storage of samples at ambient and Refrigeration $\mathrm{T}^{\circ} \mathrm{C} 5^{\circ}$ for a period of seven weeks

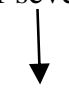

Analysis of samples

Fig. 1. Process flow for traditional meat products.

\section{B. Microbiological Analysis}

Ten grams of each sample and $90 \mathrm{ml}$ of normal sterile saline water was homogenized in a stomacher bag blender for 1-3 minutes to concentrate the suspended micro flora in them to form a food homogenate. Thereafter, different microbial flora from homogenate was isolated using several specialized isolation culture media. $0.1 \mathrm{ml}$ samples of appropriate dilutions were spread on the following media for microbial count. Nutrient agar (Oxoid), MacConkey agar (Oxoid), mannitol salt agar (oxoid) and potato dextrose agar (oxoid) for the enumeration of total viable count, E-coli, Staphylococcus aureus and yeast and mold, respectively.

\section{1) Total viable count (TVC).}

For total bacterial counts, $0.1 \mathrm{ml}$ of relevant dilutions was inoculated onto sterile nutrient agar plates and spread on the surface using sterile bent glass rod. Inoculated plates were incubated at $37^{\circ} \mathrm{C}$ for $48 \mathrm{~h}$ before colonies were counted and reported as colony forming units/g (CFU/g)).

\section{2) Escherichia coli count}

$0.1 \mathrm{ml}$ of relevant dilution was spread on surface of McConkey agar plates. The plates were then incubated for 
$24 \mathrm{~h}$ at $37^{\circ} \mathrm{C}$. Colonies were counted and reported as colony forming units/g (CFU/g).

\section{3) Staphylococcus aureus count}

$0.1 \mathrm{ml}$ of relevant dilutions was spread on mannital salt agar plates using sterile bent glass rod on. The inoculated plates were incubated at $37{ }^{\circ} \mathrm{C}$ for $48 \mathrm{~h}$. Colonies were counted and reported as colony forming units/g (CFU/g).

\section{4) Mould and yeast count}

Yeasts and mold were enumerated by the surface plate method using potato dextrose agar (PDA). $0.1 \mathrm{ml}$ of appropriate sample dilutions were spread onto PDA agar and incubated at $25{ }^{\circ} \mathrm{C}$ for 3-5 days. Colonies were counted and reported as colony forming units/g (CFU/g))

\section{Quality Indices}

The peroxide value, free fatty acid, $\mathrm{pH}$ thiobarbituric acid (TBA) and the acid value were analysed to determine the chemical quality of traditional meat products.

\section{1) Determination of Peroxide Value (PV)}

Two grams of sample were weighed into a glass stoppered flask. Twenty five milliliters of acetic acid- chloroform mixture (in ratio 3:2) was added and the sample dissolved. One milliliter of saturated potassium iodide (KI) solution (4 parts KI in 3 parts distilled water) was added, mixed, and placed in the dark for $10 \mathrm{~min}$. Thirty milliliters of distilled water was added, mixed and followed by addition of $1 \mathrm{ml}$ of $1 \%$ starch indicator. The mixture was titrated with $0.01 \mathrm{~N}$ sodium thiosulphate until the blue colour disappeared. A blank test containing all the reactants other than sample was carried out at the same time. The peroxide value of each sample was calculated as follows:

$$
\mathrm{PV} \%\left(\frac{\mathrm{meq}}{100 \mathrm{~g}}\right)=(\mathrm{B}-\mathrm{A}) \times 1000 \times \mathrm{N} / \mathrm{W}
$$

where

$\mathrm{B}-1^{\text {st }}$ titre;

A - blank;

$\mathrm{N}$ - Normality of $\mathrm{Na}_{2} \mathrm{~S}_{2} \mathrm{O}_{4}$;

$\mathrm{W}-$ Weight of samples (g).

\section{2) Determination of $p H$}

The $\mathrm{pH}$ of meat was measured by mixing $5 \mathrm{~g}$ of sample with $20 \mathrm{ml}$ of deionized water and stirred for 5minutes and measured using $\mathrm{pH}$ meter (Hanna $\mathrm{pH}$ meter 213).

\section{3) Determination of free fatty acid}

Free fatty acid (\% of oleic acid) were analyzed by using standard method: $2 \mathrm{~g}$ of sample was weighed into a $250 \mathrm{ml}$ conical flask and $10 \mathrm{ml}$ of ethanol (95\%) was added, the resulting mixture was titrated with sodium hydroxide $(0.1 \mathrm{M})$ using phenolphthalein as indicator. The titration was done with constant shaking until a pink colour persisted for 30 seconds. The \%FFA was then calculated from the following equation:

$$
\% \mathrm{FFA}=(1 \text { st titre } \times 282 \times \mathrm{N}) /(\mathrm{F} \times \mathrm{W})
$$

where

W - Weight of sample (g);

$\mathrm{N}$ - Normality NaoH;
F - Factor, (10);

282 - Conversion factor for $\mathrm{m} / \mathrm{w}$ (oleic acid).

\section{4) Determination of Acid value}

About $2.5 \mathrm{~g}$ of meat sample slurry was weighed out into a $100 \mathrm{ml}$ beaker and $50 \mathrm{ml}$ of distilled water added. The sample was then titrated with $0.1 \mathrm{~N} \mathrm{NaOH}$ in the presence of phenolphthalein indicator until the end-point was reached, signified by a change of indicator colour to pink. The volume (ml) of $\mathrm{NaOH}$ used was recorded and used in determining \% acid.

$$
\begin{aligned}
& \text { Acid value } \%=\mathrm{ml} \text { of } \mathrm{NaOH} \times 0.1 \mathrm{~N} \mathrm{NaOH} \\
& \times \text { milliequavalent factor } \times 100 /(\mathrm{W})
\end{aligned}
$$

where

$\mathrm{W}$ - Weight of sample (g);

$\mathrm{N}$ - Normality $\mathrm{NaoH}$;

$\mathrm{M} / \mathrm{w}$ (oleic acid).

\section{5) Determination of Thiobarbituric Acid Reactive Substances (TBARS)}

Analytical Procedure: The standard malondialdehyde (MDA) solution $(1 \mathrm{ml})$ was taken in a $10 \mathrm{~mL}$ test tube and mixed with Thiobarbituric Acid ((TBA) $(1 \mathrm{ml})$. The mixture was heated in a boiling water bath at $95{ }^{\circ} \mathrm{C}$ for 60 minutes. The test tubes were cooled at room temperature and absorbance was measured at $532 \mathrm{~nm}$ using UV-visible spectrophotometer model PharmaSpec 1800 (Shimadzu, Japan). Each standard for the calibration was repeated according to the above procedure. A blank sample was repeated

Preparation of malondialdehyde (MDA) and Calibration Standards: Standard stock solution of MDA (1 mM) was prepared in glacial acetic acid. MDA (31.35 mg) was accurately weighed and dissolved in $100 \mathrm{~mL}$ solvent. From the stock solution, different concentrations of $0.1,0.2,0.4$, 0.6 , and $0.8 \mathrm{mM}$ were prepared. The calibration curve was constructed in the concentration range of 0.1 to $1.0 \mathrm{mM}$.

Extraction of ThioBarbituric Acid Reactive Substances (TBARS) in Samples: One gram of ground meat sample was taken in $25 \mathrm{~mL}$ test tube and $5 \mathrm{~mL}$ of the solvent. The solvent was either $100 \%$ glacial acetic acid (AA) or $50 \%$ glacial acetic acid in water (AW). The extract of each sample $(1 \mathrm{ml})$ was mixed with $1 \mathrm{ml}$ TBA reagent, and the above procedure was repeated five times. The TBARS was calculated using the formula as $\mathrm{M} / \mathrm{g}$ of the sample: where the amount is determined from the calibration curve and the weight of the sample taken.

The TBARS was calculated using the formula in $\mu \mathrm{M} / \mathrm{g}$ of the sample as:

$$
\text { TBARS in }(\mu \mathrm{M} / \mathrm{g})=\frac{\mathrm{Ac} \times \mathrm{V}}{\mathrm{W}}
$$

where

Ac is the amount determined from the calibration curve; $\mathrm{W}$ is the weight of the sample taken;

$\mathrm{V}$ is volume in $\mathrm{mL}$ or dilution factor of the total extract prepared. 


\section{Data Analysis}

The data obtained were subjected to analysis of variance (ANOVA) to evaluate microbial and chemical quality characteristic of traditional meat products. When significant difference was observed between the samples for a parameter, LSD (Least Significant Difference) test to identify the means that are different. Statistical significance was measured at $(\mathrm{P}<0.05)$ using SPSS Version 19.0 software and Microsoft office excel was also used to generate tables and bar graphs. The data were expressed as mean count \pm standard error of mean.

\section{RESULTS AND DISCUSSIONS}

\section{A. Changes in Microbial counts during Storage at Different Temperature Conditions}

Result presented in (Fig. 2) showed that there were viable microorganisms as indicated by the total viable count, Staphylococcus aureus and yeast and mold for the period of seven weeks observed at ambient temperature.

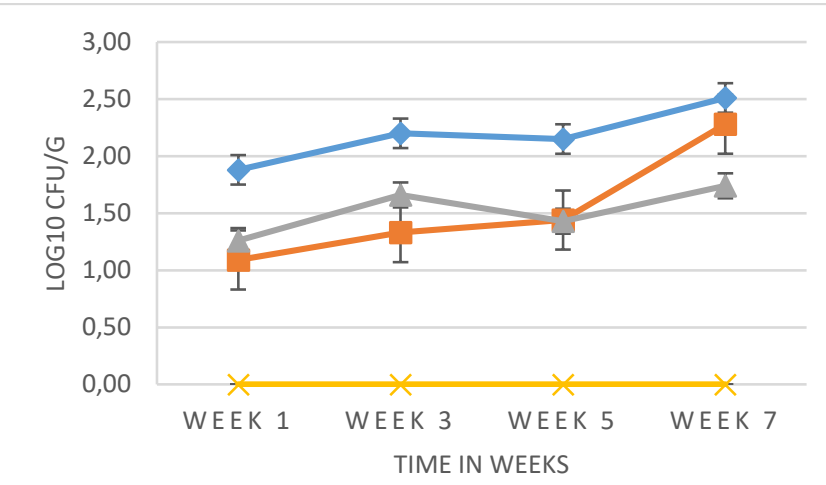

$\leadsto$ TVC $\longrightarrow$ S. aureus $\leadsto$ Yeast \& Mold $\leadsto$ E. coli

Fig. 2.: Changes in counts $\left(\log _{10} \mathrm{CFU} / \mathrm{g}\right)$ at ambient temperature conditions observed biweekly for seven weeks.

The result further indicates that, there was significant $(\mathrm{p}<0.05)$ increase of Staphylococcus aureus from $\left(1.28 \log _{10}\right.$ $\mathrm{CFU} / \mathrm{g}))$ to $\left(2.28 \log _{10} \mathrm{CFU} / \mathrm{g}\right)$ over the observed period at ambient temperature. However, for all the microorganisms analysed the counts were within acceptable limit as stated by [9] that require any cooked food to contain no more than $10^{6}$ viable counts per gram upon analysis. From all the samples tested Escherichia coli was not detected (ND). The presence and increase of microbial count during the time observed could be attributed to cross and post handling contamination [10]. Observed that the application of high temperature during roasting and the process of drying of the meat were expected to have reduced the bacterial load of the meat product. However, the presence of bacterial counts despite these processes suggests possible post-production contamination. Yeast and molds can cause spoilage of jerky a dried meat products during storage of the product acquires moisture from the environment [11].

Comparing the samples stored at ambient temperature and refrigerated temperature $\left(5^{\circ} \mathrm{C}\right)$ (Fig. 2 and 3), showed that there was decline in counts observed for total viable count, Staphylococcus aureus and yeast and molds in refrigerated temperature (2.51 to $1.91 \log _{10} \mathrm{CFU} / \mathrm{g}$ ); 2.28 to $0.63 \log _{10}$ CFU/g) and 1.74 to $1.21 \log _{10} \mathrm{CFU} / \mathrm{g}$ )), respectively. This shows that temperature condition during storage do have an effect on microbial growth and keeping quality of this traditional meat products. Cool (or chill) storage refers to storage at temperatures from about 16 to $-2{ }^{\circ} \mathrm{C}$. Chemical reaction rates decrease as temperatures decrease [12].

Escherichia coli was the best faecal indicator organism to assess sanitation conditions during processing because of their high prevalence in the faeces of healthy animals [13] The presence of Staphylococcus aureus and yeast and molds of counts in traditional meat products indicate that there was post cooking contamination at ambient temperature. Staphylococcus aureus may be present in small numbers in dried meat and is frequently introduced into foods by way of abscesses or the nasal cavity of food handler's [14]. Smoke constituents play an important role in preserving the product against microbial spoilage. [15]

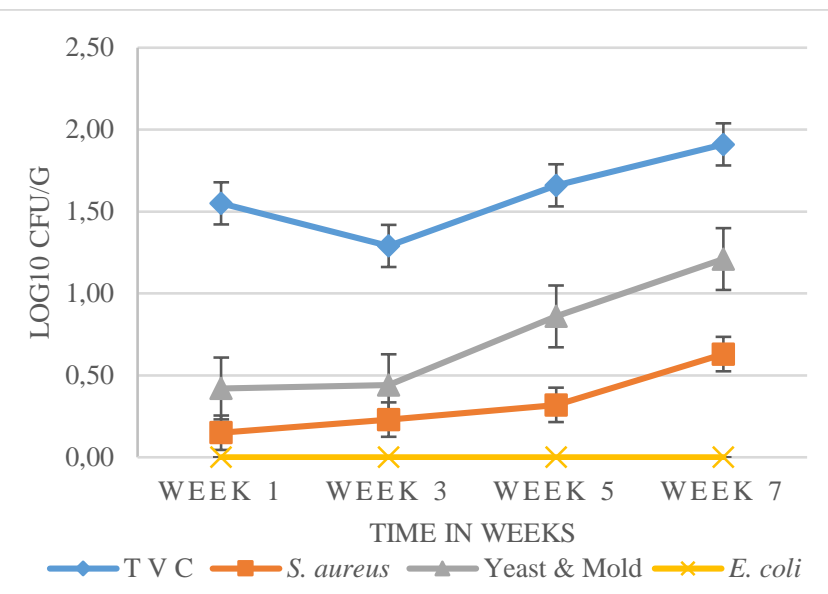

Fig. 3. Changes in counts $\left.\left(\log _{10} \mathrm{CFU} / \mathrm{g}\right)\right)$ at refrigerated temperature $\left(5^{\circ} \mathrm{C}\right)$ conditions observed biweekly for seven weeks.

\section{B. Different Storage Containers and Temperature}

For the storage containers, (Fig. 4) Results indicate that there were microbial counts observed in all the threecontainer type at ambient temperature. However, stainlesssteel containers had higher counts for total viable count, Staphylococcus aureus and yeast and molds more than the universal glass bottle and traditional containers. This could have attributed to pre-drying of meat products and that the traditional container was fumigated and smoked by special kind of stick. It was reported pastoralist normally fumigate their food containers for preservation of meat and milk.

Result in (Fig. 5) for storage containers stored at refrigerated temperature $\left(5^{\circ} \mathrm{C}\right)$, revealed that there was significant $(\mathrm{p}<0.05)$ decline in growth of Staphylococcus aureus count for all the three containers at refrigerated temperature $\left(5^{\circ} \mathrm{C}\right)$.

However, there was presence of viable microorganisms and yeast, and molds counts. Although cooking destroys Staphylococcus aureus, the toxin it produces is heat stable. Refrigeration of raw and cooked foods will inhibit the growth of Staphylococcus aureus out of foods [16].

A significant difference in microbial load reduction was observed with different storage temperatures conditions and in products stored in universal glass bottles and traditional 
containers. Proper handling, pre-treatment and preservation techniques can improve the quality of meat and meat products and increase their shelf life [17].

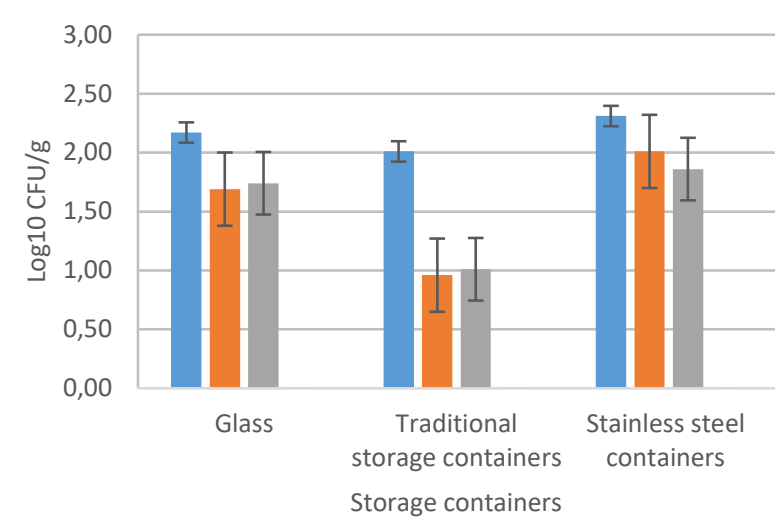

Total Viable Counts S.aureus Yeast \& mold E.coli

Fig. 4. Microbial counts $\left.\left(\log _{10} \mathrm{CFU} / \mathrm{g}\right)\right)$ observed in different storage containers at ambient temperatures at week one.

A study by [18] found that aerobic plate count for jerky which is sold as heat treated ready to eat meat products was detected at levels considered safe for human consumption at 3.21 to $3.45 \log _{10} \mathrm{CFU} / \mathrm{g}$ ) over ambient storage of 28 days. Similarly [19] reported that biltong, a dried salted beef product in South Africa, had aerobic bacteria (6.4 to $7.0 \log _{10}$ $\mathrm{CFU} / \mathrm{g})$, staphylococcus aureus $\left(3 \log _{10} \mathrm{CFU} / \mathrm{g}\right.$ and E. coli $(1$ $\log _{10} \mathrm{CFU} / \mathrm{g}$ counts, yeast, and mold $6 \log _{10} \mathrm{CFU} / \mathrm{g}$.

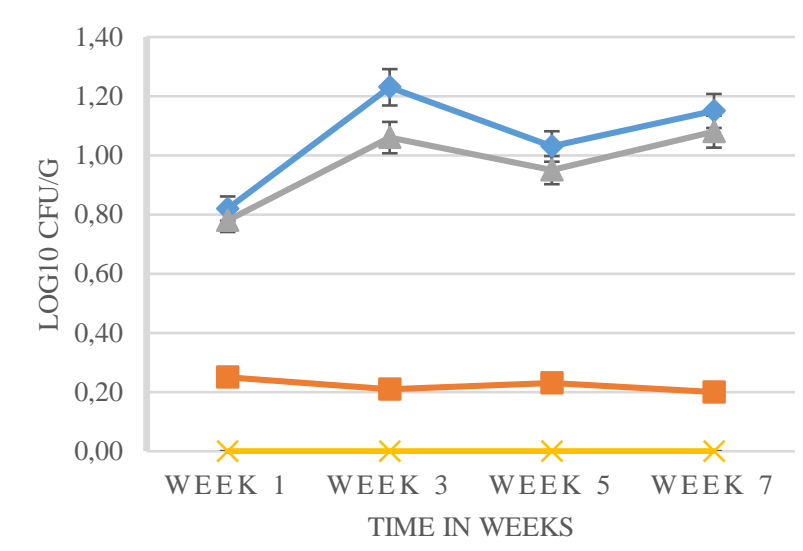

$\longrightarrow \mathrm{T} \mathrm{V} \mathrm{C} \longrightarrow$ S. aureus $\longrightarrow$ Yeast \& Mold $\longrightarrow$ E. coli

Fig. 5. Microbial counts $\left.\left(\log _{10} \mathrm{CFU} / \mathrm{g}\right)\right)$ observed at refrigerated temperature $\left(5^{\circ} \mathrm{C}\right)$ at week one.

This indicates that total bacterial count, staphylococcus aureus, yeast and mold in traditional meat is lower at 2.51 $\log _{10} \mathrm{CFU} / \mathrm{g} 2.28 \quad \log _{10} \mathrm{CFU} / \mathrm{g}$ and $1.74 \log _{10} \mathrm{CFU} / \mathrm{g}$ respectively than has been reported for biltong and jerky.

\section{Different Storage Containers and Improved Processing Conditions}

Fig. 6 shows result of storage containers with samples prepared under traditional conditions and improved conditions where basic hygiene of washing hands at critical stages were observed. There was significant $(\mathrm{p}<0.05)$ decline in growth of Staphylococcus aureus counts for all the three storage containers in improved samples.

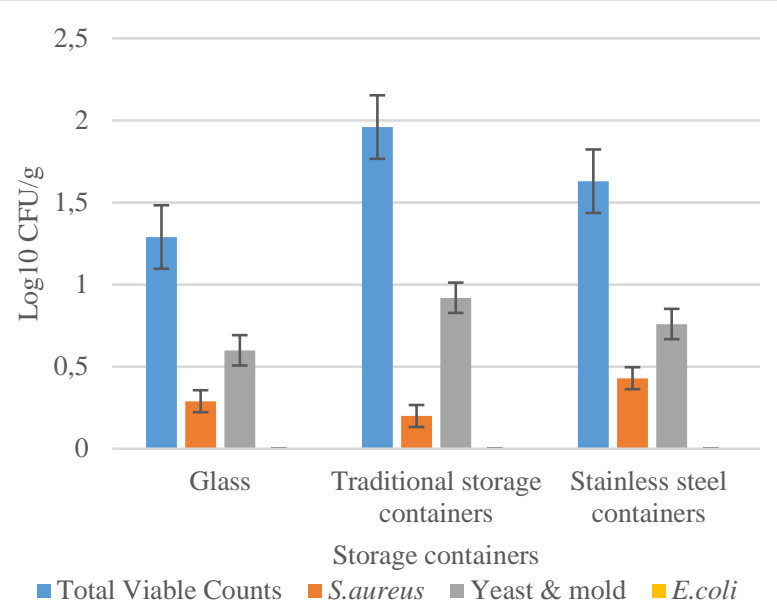

Fig. 6. Changes in mean counts $\left.\left(\log _{10} \mathrm{CFU} / \mathrm{g}\right)\right)$ observed for seven weeks for product processed under improved condition.

Total viable count and yeast and molds counts were also lower in improved products [20] Described that the art of preserving meat by a combination of salting, spicing and exposure to the sun for drying has been practiced for centuries in nearly every country, especially in developing countries where refrigeration is limited or unavailable. Moisture and temperature developments during drying are indicators of the quality and safety of foods [21].

\section{Effect of Different Processing Conditions on Microbial Populations}

Comparing the traditional meat prepared under traditional condition by women and improved condition where basic hygiene was observed, the result in (Fig. 7) shows lower counts in all the three, total viable count at $\left(1.23 \log _{10}\right.$ $\mathrm{CFU} / \mathrm{g}$ )) and no counts for Staphylococcus aureus and yeast and molds at seven weeks. This was attributed to the basic hygiene and monitoring critical meat preparations stages (before and during) processing of traditional meat products.

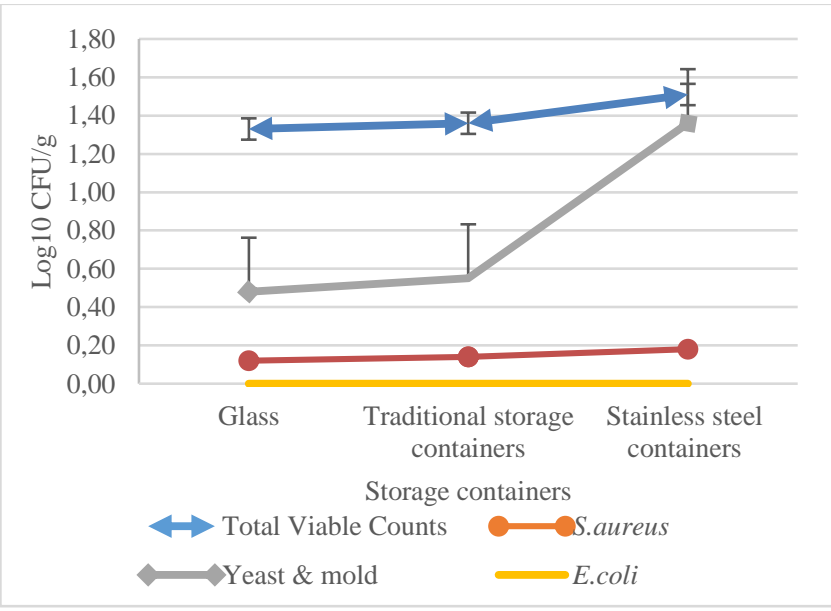

Fig. 7. Changes in mean counts $\left(\log _{10} \mathrm{CFU} / \mathrm{g}\right)$ in storage containers for improved products.

\section{E. Quality Indices}

Table I contains the quality indices of processed traditional meat products. There was no significant difference observed 
in $\mathrm{pH}$ values (5.9-6.0). [23] Reported that $\mathrm{pH}$ of beef kitoza ranged from 5.26 to 6.22 ) similar to the $\mathrm{pH}$ of salted/dried beef products such as pastirma (5.7-6.1.) The acid value is the number of milligrams of sodium (or potassium) hydroxide necessary to neutralize the free acids in 1 gram of sample. The acid value is a measure of the amount of free acids present in a given amount of sample.

\begin{tabular}{|c|c|c|c|c|}
\hline Quality Indices & Beef (Koche) & Goat (koche) & Beef pounded & Mix Beef and barley \\
\hline $\mathrm{pH}$ & $5.93^{\mathrm{a}} \pm 0.18$ & $6.18^{\mathrm{a}} \pm 0.08$ & $5.71^{\mathrm{a}} \pm 0.05$ & $5.85^{\mathrm{a}} \pm 0.03$ \\
\hline Peroxide value $\mathrm{mEq} / \mathrm{kg}$ & $2.41^{\mathrm{a}} \pm 0.81$ & $2.56^{\mathrm{b}} \pm 0.80$ & $2.68^{\mathrm{b}} \pm 0.82$ & $1.81^{\mathrm{c}} \pm 0.81$ \\
\hline TBA mg MDA/kg & $0.53^{\mathrm{a}} \pm 0.01$ & $0.42^{\mathrm{b}} \pm 0.02$ & $0.54^{\mathrm{a}} \pm 0.02$ & $0.33^{\mathrm{c}} \pm 0.02$ \\
\hline Acid value $\%$ & $0.01^{\mathrm{a}} \pm 0.00$ & $0.01^{\mathrm{a}} \pm 0.00$ & $0.0^{0 \mathrm{a}} \pm 0.00$ & $0.00^{\mathrm{a}} \pm 0.00$ \\
\hline Free fatty acid $\%$ & $2.62^{\mathrm{a}} \pm 0.01$ & $1.41^{\mathrm{b}} \pm 0.02$ & $0.84^{\mathrm{c}} \pm 0.02$ & $0.14^{\mathrm{d}} \pm 0.00$ \\
\hline
\end{tabular}

Preventive measures can be applied at the most critical stages of preparation, storage, or display and wherever control is feasible. Home preservers should always wash their hands and sanitize utensils and work surfaces before and after processing [22] Escherichia coli was not detected in any samples of traditional meat products. Dried meat products are shelf stable at ambient temperature. As a loose reference to determine approximately where spoilage will occur, preserved meat should have aerobic colony count less than 6 $\left.\log _{10} \mathrm{CFU} / \mathrm{g}\right)$, Escherichia coli none detected, yeast and mould less than $3 \log _{10} \mathrm{CFU} / \mathrm{g}$ ) and Staphylococcus aureus< $1.3 \log _{10} \mathrm{CFU} / \mathrm{g}$ ) [14]. The Acid value percent was constant and there was no variation noted.

In this study, the Peroxide Value (PV) of the processed samples was $1.8-2.7 \mathrm{mEq} / \mathrm{kg}$. These values are within the value for prevention and control of rancidity development in meat. The peroxide value is a useful method to determine the early stages of fat oxidation and the product is considered rancid when PV of 20-40 meq kg-1 is reached [22].

Free fatty acids values of processed meat products were $0.14-2.62 \%$. These values were below the threshold for rancidity detection in dried cooked meat. Thiobarbituric acid (TBA) values expressed as $\mathrm{mg}$ of malondialdehyde (MDA) $/ \mathrm{kg}$ of processed products were $0.33-0.54$ (MDA) $/ \mathrm{kg}$ hence, it was within the acceptable range. TBA value is routinely used as an index of assessing lipid oxidation in meat products during storage [24] reported that the rancid flavour is initially detected in meat products at TBA values of 2.0 a threshold value of $2 \mathrm{mg} / \mathrm{kg}$.

Peroxide value (PV) was used as indices to assess the level of lipid oxidation and it is widely used for the estimation of oxidative rancidity in fats and oils [25] There was significant increase $(\mathrm{p}<0.05)$ for peroxide value 2.26 to $4.45 \mathrm{mEq} / \mathrm{kg}$ at week one and week seven [26] reported significant changes in peroxide value $(\mathrm{p}<0.01)$ due to storage period in meat samples.

The result of quality indices, the $\mathrm{pH}$, peroxide value (PV), Acid value, FFA (free fatty acid) and TBA (Thiobarbituric acid) are presented in (Fig. 8) was monitored at week one as basis to compare at week seven during storage period to observe changes in the keeping quality which shows no significant variation $(\mathrm{p}>0.05)$ for $\mathrm{pH}$, acid vale and TBA.

Free fatty acids are the products of enzymatic or microbial degradation of lipids. The mean values of the free fatty acids $(\%$ oleic acid) of samples increased significantly $(\mathrm{p}<0.05)$ from $0.97 \%$ to $2.05 \%$ at week 1 and week 7 respectively [27] reported that FFA level of kilishi during 14 days storage was about $1.8 \%$, which implied that kilishi maintain a good quality at a considerably long period of storage.

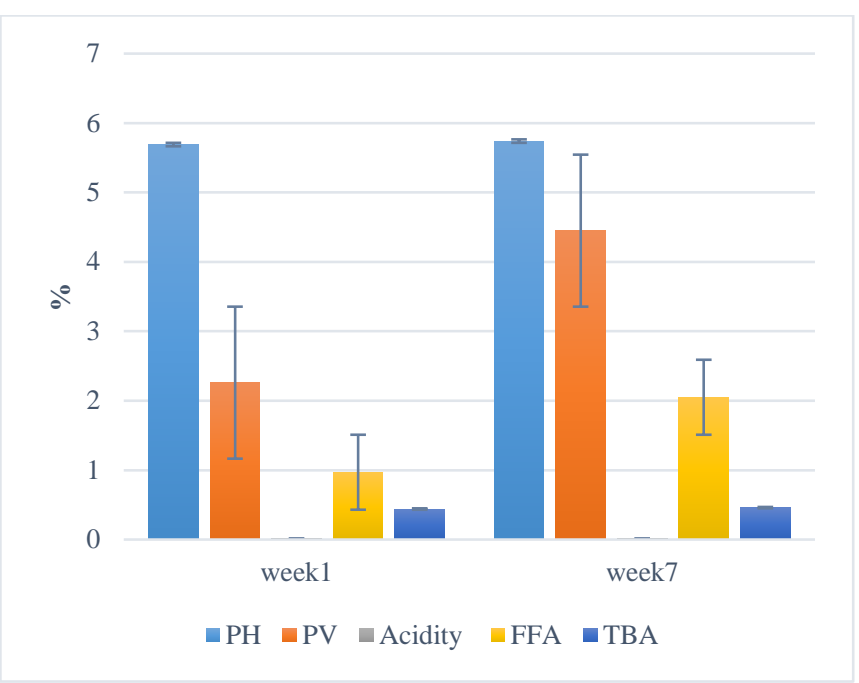

Fig. 8. Changes in quality indices at week 1 and week 7.

\section{CONCLUSION}

Results obtained from microbiological and rancidity indices were within acceptable range throughout the storage period. Drying and cooking of meat contributed towards reduction of microbial load. It was noted that refrigerated temperature, good hygiene practices, glass containers and traditional storage containers were practices observed to have good keeping qualities and enhanced safety for traditional meat products. However, poor handling and post contamination led to proliferation of microbes. Low moisture, low temperature, and observation of good hygiene practices prior and during processing of traditional meat products were practices observed to enhance the shelf life and quality of traditional meat products.

\section{CONFLICT OF INTEREST}

The authors declare that there is no conflict of interest

\section{ACKNOWLEDGEMENT}

The author would like to acknowledge and appreciate the RELOAD (Reducing Losses Adding Value) Project.

\section{REFERENCES}

[1] I. E. Zaier, M. Chabbouh, S. Bellagha, and A. Sahli, "Physicochemical and microbial characteristics of traditional and industrial kaddid," European Drying Conference. Palma. Balearic Island, Spain. 2011. 
[2] M. I. Matsheka, S. Mpuchane, B. A. Gashe,, J.Allotey, E. B. Khonga, S. H. Coetzee, G. Murindamombe "Microbial Quality Assessment and Predominant Microorganism of Biltong Produced in Butcheries in Gaborone, Botswana," Food and Nutrition Sciences, vol. 05, no. 17, pp. 1668-1678, 2014, doi: 10.4236/fns.2014.517180.

[3] D. Dave and A. E. Ghaly, "Meat spoilage mechanisms and preservation techniques: a critical review," American Journal of Agricultural and Biological Science, 6 (4): 486-510, ISSN 1557-4989 CScience Publications. 2011.

[4] Y. H. Hui, 'Handbook of Meat and Meat Processing', Second Edition, CRC Press, Technology and Engineering, 2012.

[5] D. Burfoot, L. Everis, L. Mulvey, A. Wood, and R. B. Campden, "Literature review on microbiological hazards associated with biltong and similar dried meat products," Food Standard Agency, London, vol. 87, 2010.

[6] S. A. Datta, A. Akter, I. G. Shah K. Fatema, T. Islam, H.A. BandyopadhyayZ U, M Khan, Z. U. M. and D Biswas, Microbiological quality assessment of raw meat and meat products and antibiotic susceptibility of isolated Staphylococcus aureus. J. Agric. Food Anal. Bacteriol., 2: 187-195. 2012.

[7] F. S. Hassanien, M. A. El-Shater, and R. R. Abd El-Fatah, "Bacteriological aspect of meat and poultry meat meals," Benha Veterinary Medical Journal, vol. 28, no. 2, pp. 91-97, 2015.

[8] AOAC, Official Methods of Analysis (17 $7^{\text {th }}$ ed.). Association of Analytical Chemists International, Gaithersburg, MD., USA. 1995.

[9] KEBS (Kenya bureau of standards) Kenya standards East African Standards (KS EAS) 2003.

[10] A. I. Raji, "Bacteriological quality of dried sliced beef (Kilishi) sold in Ilorin Metropolis," Journal of Applied Sciences and Environmental Management, vol. 10, no. 1, pp. 93-96, 2006.

[11] W. Sperber, and M. Doyle. Compendium of the Microbiological Spoilage of Foods and Beverages, Springer New York Dordrecht Heidelberg London. ISBN 978-1-4419-0825-4 e-ISBN 978-1-44190826-1 DOI 10.1007/978-1-4419-0826-1. 2009.

[12] T. J. Montville and K. R. Matthews, Food microbiology: an introduction, 2nd ed. Washington, DC: ASM Press, 2008.

[13] D.K. Byarugaba, R., Kisame and S. Olet, Multi-drug resistance in commensal bacteria of food of animal origin in Uganda. Afr. J. Microbiol. Res. 5(12): 1539-1548. 2011.

[14] N. Garg, K. L. Garg, and K.G. Mukerji, Laboratory manual of food microbiology. New Delhi: I.K. International Publishing House Pvt. Ltd. 2010.

[15] P. O. Fakolade, and A. B. Omojola, 'Proximate composition, pH value and microbiological evaluation of Kundi (dried meat) product from beef and camel meat'. http://www.tropentag.de/2008/abstracts/full/38.pdf_2008.

[16] A. B. Wagner, Bacteriological food poisoning, http://aggie horticulture tamu. Edu/extension/poison. 2001.

[17] D. Dave and A. E Ghaly, Meat Spoilage Mechanisms and Preservation Techniques: A Critical Review. American Journal of Agricultural and Biological Sciences 6 (4): 486-510, ISSN 1557-4989 CScience Publications 2011.

[18] M.M. Tajkarim, S.A. Ibrahim, D. O. Cliver, 'Antimicrobial herb and spice compounds in food', Food Control, 21, 1199-18. 2010.

[19] S. G. Mhlambi, K. Naidoo, and D. Lindsay, "Enterotoxin-Producing Staphylococcus Strains Associated with South African Biltong at Point of Sale," Journal of Food Safety, vol. 30, no. 2, pp. 307-317, 2010. https://doi.org/10.1111/j.1745-4565.2009.00208.x.

[20] H. Purnomo, 'Physicochemical and microbial quality of indigenous Indonesian spicy dried meat'. International Journal of Food Sciences $\begin{array}{llll}\text { and } \quad 62 & (2): 133-38 . & 2011 .\end{array}$ doi:10.3109/09637486.2010.513681. [Taylor \& Francis Online], [Web of Science $\left.{ }^{\circledR}\right]$.

[21] M. Soydan Karabacak, A. Esin, and D. Cekmecelioglu, "Drying Behavior of Meat Samples at Various Fiber Directions and Air Conditions," Drying Technology, vol. 32, no. 6, pp. 695-707, 2014. https://doi.org/10.1080/07373937.2013.855784.

[22] A. Nummer, J. A. Harrison, M. A. Harrison, P. Kendall, J. N. Sofos, and E. L. Andress, "Effects of preparation methods on the microbiological safety of home-dried meat jerky," Journal of food protection, vol. 67, no. 10, pp. 2337-2341, 2004.

[23] A.Ratsimba, D. Rakoto and V. Jeannoda. Physicochemical and microbiological characteristics of kitoza, a traditional salted/dried/smoked meat product of Madagascar. Food Sci Nutr. 7:2666-2673. 2019. https://doi. org/10.1002/fsn3.1122.

[24] W.H. Raja, S. Kumar, and Z. F. Bhat, Effect of ambient storage on the quality characteristics of aerobically packaged fish curls incorporated with different flours. SpringerPlus 3, 106.2014. https://doi.org/10.1186/2193-1801-3-106.
[25] M. I. Aksu, The effect of $\alpha$-tocopherol, storage time and storage temperature on peroxide value, free fatty acids and $\mathrm{pH}$ of kavurma, a cooked meat product. Journal Muscle Foods. 18(4):370-9. 2007.

[26] A. B. Soyer and U. Ozalp, Effects of freezing temperature and duration of frozen storage on lipid and protein oxidation in chicken meat. Food Chem., 120: 1025-1030. 2010.

[27] O. Idowu, K. O. Falade, and T.O. Omobuwajo, Production, proximate analysis and shelf life studies of ready-to-eat (RTE) rice and kilishi. African Journal of Food Science. 4:264-268. 2010. 